\title{
Identification of 56 Proteins Involved in Embryo-Maternal Interactions in the Bovine Oviduct
}

\author{
Charles Banliat 1,2, Guillaume Tsikis 1, Valérie Labas 1,3, Ana-Paula Teixeira-Gomes 3,4, \\ Emmanuelle Com 5,6, Régis Lavigne ${ }^{5,6}$, Charles Pineau ${ }^{5,6}$, Benoit Guyonnet ${ }^{2}$, \\ Pascal Mermillod ${ }^{1}(\mathbb{D})$ and Marie Saint-Dizier ${ }^{1,7, * \mathbb{D}}$ \\ 1 INRAE, CNRS, Université de Tours, IFCE, UMR PRC, 37380 Nouzilly, France; charles.banliat@inra.fr (C.B.); \\ guillaume.tsikis@inra.fr (G.T.); valerie.labas@inra.fr (V.L.); pascal.mermillod@inra.fr (P.M.) \\ 2 Union Evolution, 35530 Noyal-sur-Vilaine, France; benoit.guyonnet@evolution-xy.fr \\ 3 INRAE, Université de Tours, CHU de Tours, Plate-forme CIRE, PAIB, 37380 Nouzilly, France; \\ ana-paula.teixeira@inra.fr \\ 4 INRAE, UMR 1282 ISP, 37380 Nouzilly, France \\ 5 Inserm, University of Rennes, EHESP, Irset (Institut de recherche en santé, environnement et \\ travail)_UMR_S 1085, 35000 Rennes, France; emmanuelle.com@univ-rennes1.fr (E.C.); \\ regis.lavigne@univ-rennes1.fr (R.L.); charles.pineau@univ-rennes1.fr (C.P.) \\ 6 Protim, Inserm U1085, Irset, Campus de Beaulieu, University of Rennes 1, Proteomics Core Facility, \\ 35000 Rennes, France \\ 7 Faculty of Sciences and Techniques, Department Agrosciences, University of Tours, 37000 Tours, France \\ * Correspondence: marie.saint-dizier@univ-tours.fr; Tel.: +33-2-47-42-75-08
}

Received: 6 December 2019; Accepted: 10 January 2020; Published: 11 January 2020

\begin{abstract}
The bovine embryo develops in contact with the oviductal fluid (OF) during the first $4-5$ days of pregnancy. The aim of this study was to decipher the protein interactions occurring between the developing embryo and surrounding OF. In-vitro produced 4-6 cell and morula embryos were incubated or not (controls) in post-ovulatory OF (OF-treated embryos) and proteins were then analyzed and quantified by high resolution mass spectrometry (MS) in both embryo groups and in OF. A comparative analysis of MS data allowed the identification and quantification of 56 embryo-interacting proteins originated from the OF, including oviductin (OVGP1) and several annexins (ANXA1, ANXA2, ANXA4) as the most abundant ones. Some embryo-interacting proteins were developmental stage-specific, showing a modulating role of the embryo in protein interactions. Three interacting proteins (OVGP1, ANXA1 and PYGL) were immunolocalized in the perivitelline space and in blastomeres, showing that OF proteins were able to cross the zona pellucida and be taken up by the embryo. Interacting proteins were involved in a wide range of functions, among which metabolism and cellular processes were predominant. This study identified for the first time a high number of oviductal embryo-interacting proteins, paving the way for further targeted studies of proteins potentially involved in the establishment of pregnancy in cattle.
\end{abstract}

Keywords: tubal fluid; fallopian tube; oviduct; embryo; bovine; cattle; proteomics; secretions; morula; $4-6$ cell

\section{Introduction}

In mammals, embryo development starts in the oviduct, a tubular organ connecting the ovary to the uterus. The bovine embryo develops up to the 16-cell or early morula stage in the oviduct, in close contact with the oviductal epithelial cells and their secretions, the oviductal fluid (OF) [1]. Important embryonic changes including the first mitotic cleavages and the embryonic genome activation, at 8-cell, occur in this oviductal micro-environment $[2,3]$. The $\mathrm{OF}$ is a dynamic and complex fluid composed 
of glycosaminoglycans, lipids, small metabolites, inorganic salts and a high number of proteins [4]. Recently, mass spectrometry (MS) techniques have considerably increased our knowledge of the OF proteomic composition in cattle [5-7]. Furthermore, extracellular vesicles (EVs) originating from the oviduct epithelium have recently been identified as major components of the OF [8]. The molecular cargo of bovine oviductal EVs, including proteins, mRNA and different types of non-coding RNA including microRNA, was reported to dynamically change across the estrous cycle $[9,10]$. While embryos can be produced in vitro in the absence of the oviductal micro-environment, there is evidence that the OF plays important roles in early embryo development. Embryos developed in isolated bovine or ovine oviducts are of higher quality than their in-vitro counterparts in terms of morphology, gene expression, cryotolerance and pregnancy rates after transfer into recipients [11-13]. In the same way, in vitro development with low concentrations of OF has been shown to improve the cryotolerance and gene expression of bovine blastocysts [14]. In particular, the presence of OF in the culture medium provided a better control of cattle embryo DNA methylation $[14,15]$. Furthermore, the addition of oviductal EVs to the culture medium increased blastocyst rate, extended embryo survival and improved the quality of in vitro-produced cattle embryos $[9,16]$.

The proteins present in the OF, either within EVs or as soluble molecules, may play key roles in supporting embryo development. Indeed, the addition of purified or recombinant oviductin, an oviduct-specific estrus-induced glycoprotein, to the culture medium was reported to increase the rates of blastocyst development of goat [17] and cattle [18] embryos compared with non-supplemented controls. In another study, the presence of porcine recombinant oviductin did not enhance in vitro developmental rates but produced bovine blastocysts of higher quality regarding the expression of specific genes [19]. By immunostaining, oviductin has been shown to associate with oocytes and embryos from numerous species including the golden hamster [20,21], baboon [21,22], pig [23] and cattle [24,25]. Microscopic observation of in-vivo retrieved embryos revealed that oviductin crossed the zona pellucida and localized in the perivitelline space and inside embryo blastomeres [22-24,26,27]. Apart from oviductin, very few oviductal proteins have been identified as interacting with the early embryo. Co-incubation of bovine oocytes with biotinylated OF allowed researchers to identify six oviductal proteins of molecular masses ranging from 30 to $95 \mathrm{kDa}$ associated with the zona pellucida [28]. However, the proteins other than oviductin, at $95 \mathrm{kDa}$, remained unknown. In another study that used immunostaining and western blot on bovine oocytes pre-treated with OF, three proteins, including oviductin, osteopontin (SPP1) and lipocalin-type prostaglandin D synthase (L-PGDS), were shown to associate with the zona pellucida [29]. Up to now, there is no information about additional oviductal proteins that may interact with the cattle embryo. Furthermore, whether the embryo-oviduct molecular interactions vary according to the developmental stage of the embryo is currently not known.

The aim of this study was to identify with no a priori OF proteins interacting with the bovine embryo at the 4-6 cell and early morula stages, two oviductal stages before and after embryo genomic activation. A MS-based approach was applied to more than 400 in vitro-produced embryos, allowing the identification of new embryo-interacting proteins, some of which being stage-specific. Immunostaining confirmed that the interacting proteins were able to cross the zona pellucida and be internalized by embryos.

\section{Results}

\subsection{New Embryo-Interacting Proteins Were Identified by NanoLC-MS/MS and Changed According to the Embryonic Stage}

Among the proteins identified in the $\mathrm{OF}, 56$ were classified as interacting with embryos (i.e., detected in OF-treated embryos but not detected in controls, or detected at significantly higher abundance in OF-treated than in control embryos). The 56 embryo-interacting proteins accounted for only $0.03 \%$ of the 1707 proteins identified in the OF (see all OF proteins identified in Table S1).

In total, 4-6 cells and morulas interacted with 37 and 43 proteins, respectively (Tables 1-3), Interacting proteins accounted for $0.02 \%$ of the 1616 and 1765 proteins identified in OF-treated $4-6$ cells and morulas, respectively (see all proteins identified in embryos in Table S2). The embryo-interacting proteins changed according to the developmental stage: 
- 13 proteins interacted exclusively with 4-6 cells (Table 1).

- 19 proteins interacted exclusively with morulas (Table 2).

- 24 proteins interacted with both embryonic stages (Table 3).

Table 1. Proteins identified as interacting with embryos at the 4-6 cell stage.

\begin{tabular}{|c|c|c|c|c|}
\hline $\begin{array}{l}\text { Gene } \\
\text { Name }\end{array}$ & Protein Name & $\begin{array}{l}\text { Accession Number } \\
\text { (UniprotKB) }\end{array}$ & $\begin{array}{c}\text { Molecular Weight } \\
\text { (kDa) }\end{array}$ & $\begin{array}{l}\text { OF-Treated: } \\
\text { Control Ratio }\end{array}$ \\
\hline LZTFL1 & $\begin{array}{c}\text { Leucine zipper } \\
\text { transcription factor-like } \\
\text { protein } 1\end{array}$ & Q3ZBL4 & 35 & $\mathrm{~T}^{1}$ \\
\hline NQO1 & $\begin{array}{l}\mathrm{NAD}(\mathrm{P}) \mathrm{H} \text { quinone } \\
\text { dehydrogenase } 1\end{array}$ & Q3ZBH2 & 31 & $\mathrm{~T}^{1}$ \\
\hline ALDH1A2 & $\begin{array}{l}\text { Aldehyde dehydrogenase } \\
1 \text { family member A2 }\end{array}$ & G3X6U1 & 57 & $\mathrm{~T}^{1}$ \\
\hline HBA & Hemoglobin subunit alpha & P01966 & 15 & $\mathrm{~T}^{1}$ \\
\hline ITGA2 & $\begin{array}{l}\text { Integrin alpha-2 } \\
\text { (Fragment) }\end{array}$ & P53710 & 129 & 22 \\
\hline WARS & $\begin{array}{c}\text { Tryptophan-tRNA ligase. } \\
\text { cytoplasmic }\end{array}$ & P17248 & 54 & 8.7 \\
\hline RPS16 & $40 \mathrm{~S}$ ribosomal protein S16 & Q3T0X6 & 16 & 8.3 \\
\hline TARS & $\begin{array}{l}\text { Threonine-tRNA ligase. } \\
\text { cytoplasmic }\end{array}$ & Q3ZBV8 & 83 & 8.1 \\
\hline PFKL & $\begin{array}{c}\text { ATP-dependent } \\
\text { 6-phosphofructokinase. } \\
\text { liver type }\end{array}$ & A1A4J1 & 85 & 4.9 \\
\hline RPL6 & 60S ribosomal protein L6 & Q58DQ3 & 33 & 4.5 \\
\hline ALDH1A1 & Retinal dehydrogenase 1 & P48644 & 55 & 2.9 \\
\hline PPP2R1A & $\begin{array}{l}\text { Alpha isoform of } \\
\text { regulatory subunit A. } \\
\text { protein phosphatase } 2\end{array}$ & Q32PI5 & 65 & 2.3 \\
\hline ANXA5 & Annexin A5 & P81287 & 36 & 2.3 \\
\hline
\end{tabular}

Table 2. Proteins identified as interacting with embryos at the morula stage.

\begin{tabular}{ccccc}
\hline $\begin{array}{c}\text { Gene } \\
\text { Name }\end{array}$ & Protein Name & $\begin{array}{c}\text { Accession Number } \\
\text { (UniprotKB) }\end{array}$ & $\begin{array}{c}\text { Molecular } \\
\text { Weight (kDa) }\end{array}$ & $\begin{array}{c}\text { OF-Treated: } \\
\text { Control Ratio }\end{array}$ \\
\hline ACLY & ATP-citrate synthase & Q32PF2 & 120 & $\mathrm{~T}^{1}$ \\
\hline ACO1 & Cytoplasmic aconitate hydratase & Q0VCU1 & 98 & $\mathrm{~T}^{1}$ \\
\hline PNP & Purine nucleoside phosphorylase & P55859 & 32 & $\mathrm{~T}^{1}$ \\
\hline BLVRA & Biliverdin reductase A & A5D7K0 & 34 & 9.9 \\
\hline A2M & Alpha-2-macroglobulin & Q7SIH1 & 168 & 7 \\
\hline HBB & Hemoglobin subunit beta & P02070 & 16 & 6.7 \\
\hline APEX1 & DNA-(apurinic or apyrimidinic & P23196 & 36 & 5.8 \\
\hline
\end{tabular}


Table 2. Cont.

\begin{tabular}{ccccc}
\hline $\begin{array}{c}\text { Gene } \\
\text { Name }\end{array}$ & Protein Name & $\begin{array}{c}\text { Accession Number } \\
\text { (UniprotKB) }\end{array}$ & $\begin{array}{c}\text { Molecular } \\
\text { Weight (kDa) }\end{array}$ & $\begin{array}{c}\text { OF-Treated: } \\
\text { Control Ratio }\end{array}$ \\
\hline TAGLN2 & Transgelin-2 & Q5E9F5 & 22 & 5.8 \\
\hline LGALS3 & Galectin-3 & A6QLZ0 & 28 & 5.3 \\
\hline LGALS9 & Galectin-9 & Q3MHZ8 & 39 & 4.3 \\
\hline TBCB & Tubulin-folding cofactor B & Q5E951 & 28 & 4.3 \\
\hline YWHAQ & 14-3-3 protein theta & Q3SZI4 & 28 & 3 \\
\hline GLMN & Glomulin. FKBP associated & protein & 68 & 2.9 \\
\hline YWHAH & 14-3-3 protein eta & P68509 & 28 & 2.6 \\
\hline MAP4 & Microtubule-associated protein & P36225 & 138 & 2.3 \\
\hline TPP2 & Tripeptidyl-peptidase 2 & A5PK39 & 17 & 2.2 \\
\hline MYL6 & Myosin light polypeptide 6 & P60661 & 51 & 2 \\
\hline FKBP4 & $\begin{array}{c}\text { Peptidyl-prolyl cis-trans } \\
\text { isomerase }\end{array}$ & Q9TRY0 & 482 & 3.4 \\
\hline HUWE1 & $\begin{array}{c}\text { HECT. UBA and WWE domain } \\
\text { containing 1. E3 ubiquitin protein } \\
\text { ligase }\end{array}$ & E1BNY9 & & 2.9 \\
\hline
\end{tabular}

${ }^{1}$ Protein detected only in OF-treated embryos.

Table 3. Proteins identified as interacting with both the $4-6$ cell and morula stages.

\begin{tabular}{|c|c|c|c|c|c|}
\hline Gene Name & Protein Name & $\begin{array}{l}\text { Accession } \\
\text { Number } \\
\text { (UniprotKB) }\end{array}$ & $\begin{array}{c}\text { Molecular } \\
\text { Weight (kDa) }\end{array}$ & $\begin{array}{c}\text { 4-6 Cell } \\
\text { OF-Treated: } \\
\text { Control Ratio }\end{array}$ & $\begin{array}{c}\text { Morula } \\
\text { OF-Treated: } \\
\text { Control Ratio }\end{array}$ \\
\hline ANXA8 & Annexin A8 & Q95L54 & 37 & $\mathrm{~T}^{1}$ & $\mathrm{~T}^{1}$ \\
\hline AGR2 & $\begin{array}{c}\text { Anterior gradient 2. protein } \\
\text { disulphide isomerase family } \\
\text { member }\end{array}$ & F1N3J3 & 20 & $\mathrm{~T}^{1}$ & $\mathrm{~T}^{1}$ \\
\hline CAPS & Calcyphosin & Q0VCC0 & 21 & $\mathrm{~T}^{1}$ & 61 \\
\hline CD109 & CD109 molecule & F1MPE1 & 161 & $\mathrm{~T}^{1}$ & $\mathrm{~T}^{1}$ \\
\hline CKB & Creatine kinase B-type & Q5EA61 & 43 & $\mathrm{~T}^{1}$ & 4.1 \\
\hline CNDP2 & Cytosolic non-specific dipeptidase & Q3ZC84 & 53 & $\mathrm{~T}^{1}$ & 17 \\
\hline EPHX2 & Epoxide hydrolase 2 & F6QS88 & 63 & $\mathrm{~T}^{1}$ & $\mathrm{~T}^{1}$ \\
\hline PYGL & Glycogen phosphorylase. liver form & Q0VCM4 & 97 & $\mathrm{~T}^{1}$ & $\mathrm{~T}^{1}$ \\
\hline LRBA & $\begin{array}{l}\text { LPS responsive beige-like anchor } \\
\text { protein }\end{array}$ & E1BND6 & 316 & $\mathrm{~T}^{1}$ & 8.2 \\
\hline DCXR & L-xylulose reductase & Q1JP75 & 26 & $\mathrm{~T}^{1}$ & $\mathrm{~T}^{1}$ \\
\hline OVGP1 & Oviduct-specific glycoprotein & Q28042 & 60 & $\mathrm{~T}^{1}$ & 71 \\
\hline PTGR2 & Prostaglandin reductase 2 & Q32L99 & 38 & $\mathrm{~T}^{1}$ & $\mathrm{~T}^{1}$ \\
\hline SEPTIN2 & Septin-2 & Q2NKY7 & 41 & $\mathrm{~T}^{1}$ & 4.2 \\
\hline SARS & Serine-tRNA ligase. cytoplasmic & Q9GMB8 & 59 & $\mathrm{~T}^{1}$ & 5 \\
\hline TPPP3 & $\begin{array}{l}\text { Tubulin polymerization-promoting } \\
\text { protein family member } 3\end{array}$ & Q3ZCC8 & 19 & $\mathrm{~T}^{1}$ & $\mathrm{~T}^{1}$ \\
\hline ANXA1 & Annexin A1 & P46193 & 39 & 37 & 15 \\
\hline RNPEP & Uncharacterized protein & G3X743 & 72 & 9.6 & 4.6 \\
\hline FASN & Fatty acid synthase & Q71SP7 & 274 & 8.5 & 9.6 \\
\hline RNH1 & Ribonuclease/angiogenin inhibitor 1 & Q3SZN8 & 49 & 6.9 & 7.5 \\
\hline ANXA4 & Annexin A4 & P13214 & 36 & 5.4 & 6.5 \\
\hline
\end{tabular}


Table 3. Cont.

\begin{tabular}{|c|c|c|c|c|c|}
\hline Gene Name & Protein Name & $\begin{array}{c}\text { Accession } \\
\text { Number } \\
\text { (UniprotKB) }\end{array}$ & $\begin{array}{c}\text { Molecular } \\
\text { Weight (kDa) }\end{array}$ & $\begin{array}{c}\text { 4-6 Cell } \\
\text { OF-Treated: } \\
\text { Control Ratio }\end{array}$ & $\begin{array}{c}\text { Morula } \\
\text { OF-Treated: } \\
\text { Control Ratio }\end{array}$ \\
\hline SHTN1 & Shootin 1 & F1MUA7 & 63 & 5.3 & 4 \\
\hline ALDH9A1 & $\begin{array}{l}\text { 4-trimethylaminobutyraldehyde } \\
\text { dehydrogenase }\end{array}$ & Q2KJH9 & 54 & 4.2 & 2.9 \\
\hline ANXA2 & Annexin A2 & P04272 & 39 & 3.6 & 2.2 \\
\hline CLIC1 & $\begin{array}{l}\text { Chloride intracellular channel } \\
\text { protein } 1\end{array}$ & Q5E9B7 & 27 & 2.1 & 3 \\
\hline
\end{tabular}

${ }^{1}$ Protein detected only in OF-treated embryos.

There was no correlation between the initial abundance of the embryo-interacting proteins in the OF and their abundance in OF-treated embryos (Figure S1). Nineteen 4-6 cell-interacting proteins were detected only in OF-treated embryos and 18 were measured at a higher abundance in the OF-treated than in the control embryos (mean \pm SEM of treated:control ratio $=8.1 \pm 2.1$; range: $2.1-37$; Tables 1 and 3). For morulas, 11 proteins were detected only in OF-treated embryos and 32 measured at higher abundance in OF-treated than in controls (mean \pm SEM of treated:control ratio $=9.3 \pm 2.7$; range: $2-71$; Tables 1 and 2).

At both stages, oviductin (OVGP1) and annexins A1 (ANXA1), A2 (ANXA2) and A4 (ANXA4) were the most abundant interacting proteins in OF-treated embryos, followed in 4-6 cells by retinal dehydrogenase 1 (ALDH1A1), epoxide hydrolase 2 (EPHX2) and ATP-dependent 6-phosphofructokinase (PFKL), and for morulas, by galectin-3 (LGALS3), epoxide hydrolase 2 (EPHX2) and 14-3-3 protein theta (YWHAQ; Figure 1).

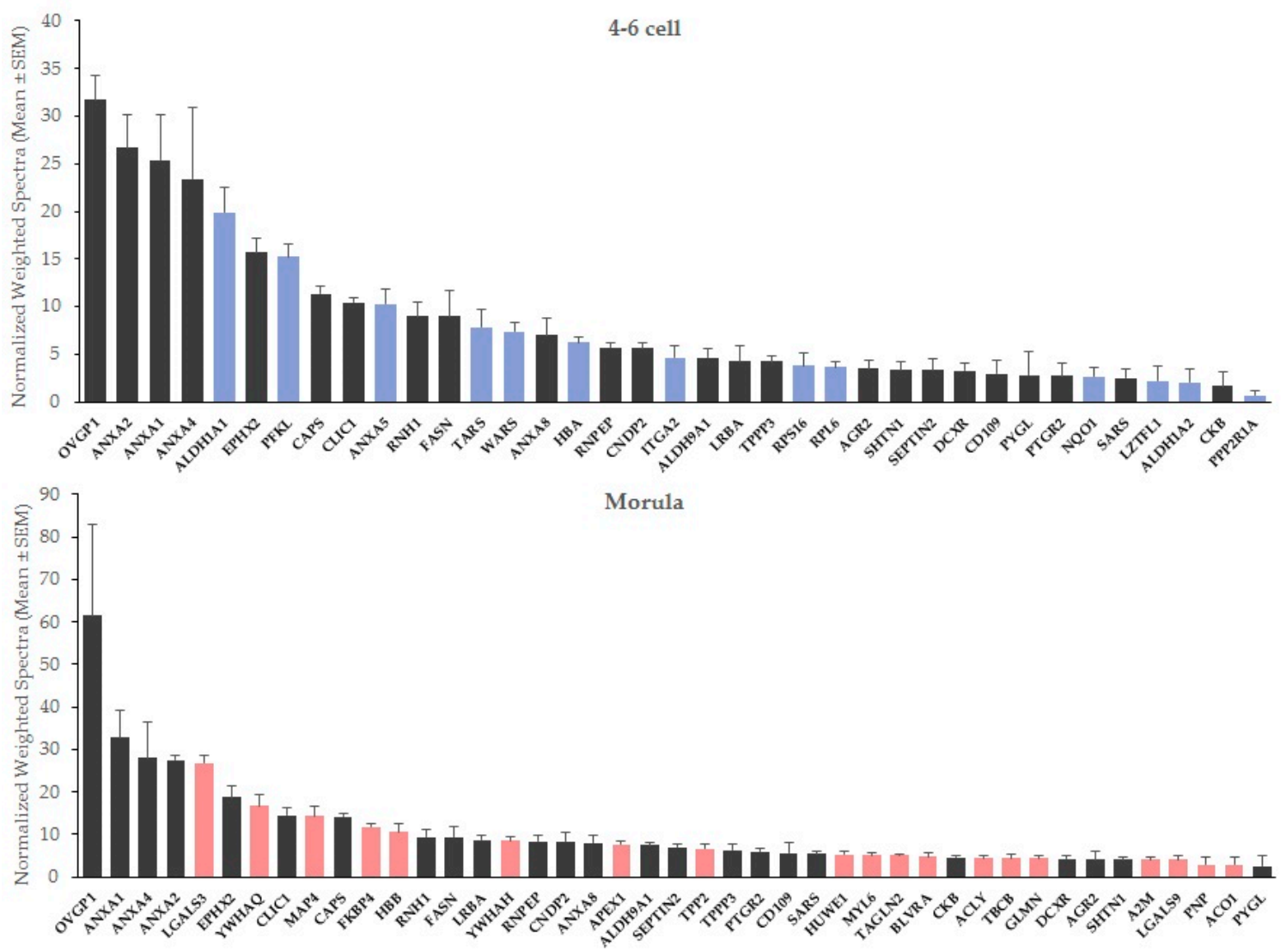

Figure 1. Mean abundance of embryo-interacting proteins in OF-treated embryos at the 4-6 cell and morula stages. Blue bars, proteins interacting exclusively with 4-6 cell embryos. Red bars, proteins interacting exclusively with morulas. 
2.2. Most Embryo-Interacting Proteins Were Presumed to be Exosomal and Secreted via Non-Conventional Pathways

Five embryo-interacting proteins $(9 \%)$ contained a signal peptide and were predicted to be secreted in a conventional way. Furthermore, 20 (36\%) were predicted to be secreted by non-classical pathways. In addition, 33 embryo-interacting proteins (59\%) were reported previously in oviductal exosomes (Figure 2) [9,30].

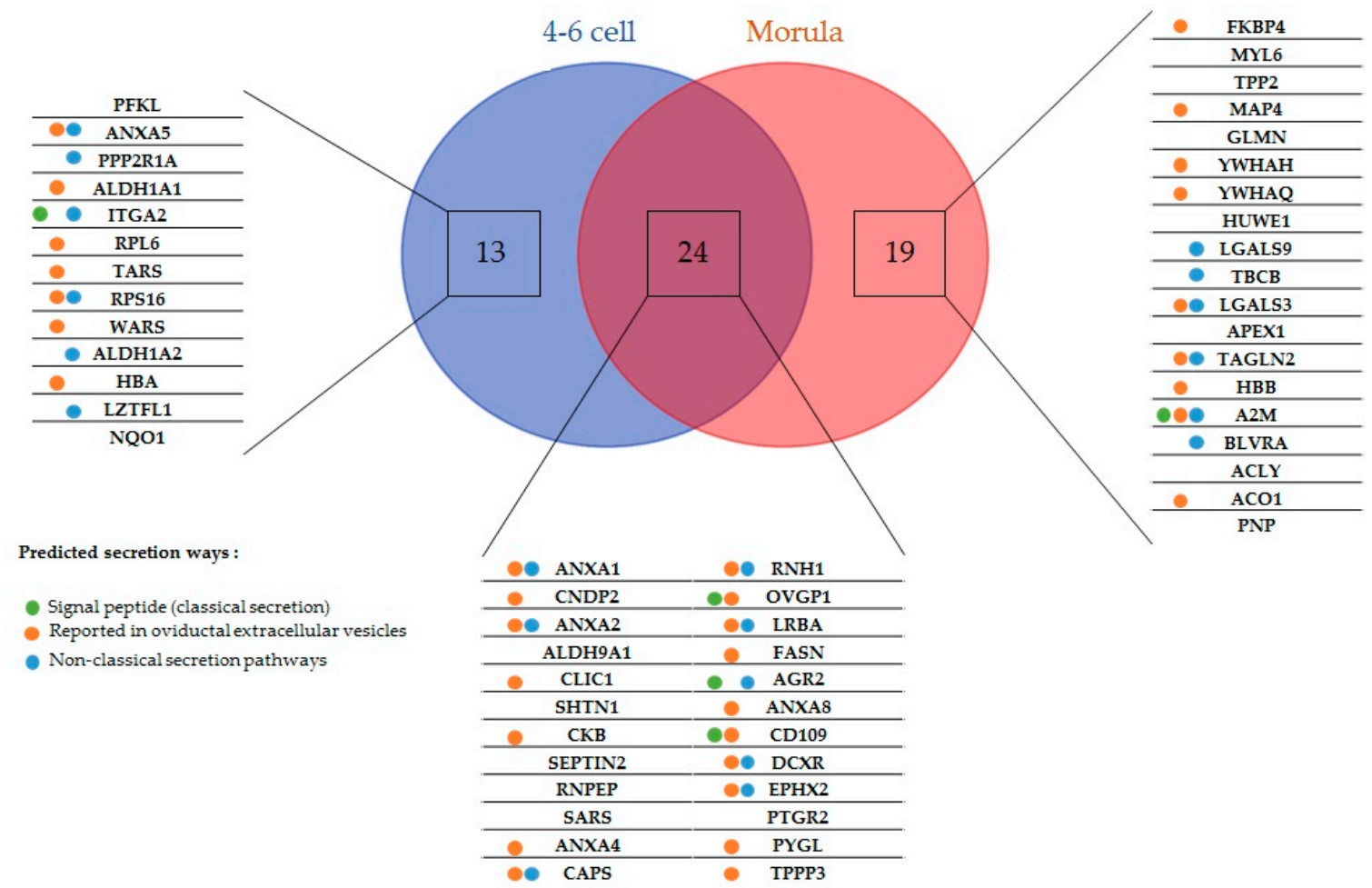

Figure 2. Embryo-interacting proteins classified according to the embryonic stage and secretion pathway. Colored spots indicate the presumed secretion pathways in oviduct epithelial cells tools. Green, proteins possessing a peptide signal and presumed to be conventionally secreted; blue, proteins predicted to be non-conventionally secreted; orange, proteins reported in bovine [9] and feline [30] oviductal exosomes.

\subsection{Embryo-Interacting Proteins Were Mainly Involved in Metabolism and Cellular Processes}

Functional annotation clustering of embryo-interacting proteins resulted in six enriched clusters, among which 'Metabolism' and 'Cellular processes' were the most significant. These findings are visualized using Proteomaps in Figure 3. Proteins such as annexins and alpha-2 macroglobulin (A2M) were assigned to the 'Exosome' category while proteins such as epoxide hydrolase 2 (EPHX2), retinal deshydrogenase 1 (ALDH1A1) and PYGL were assigned to various metabolic processes. Oviductin did not have any functional category annotation and therefore was not included in the proteomap. 

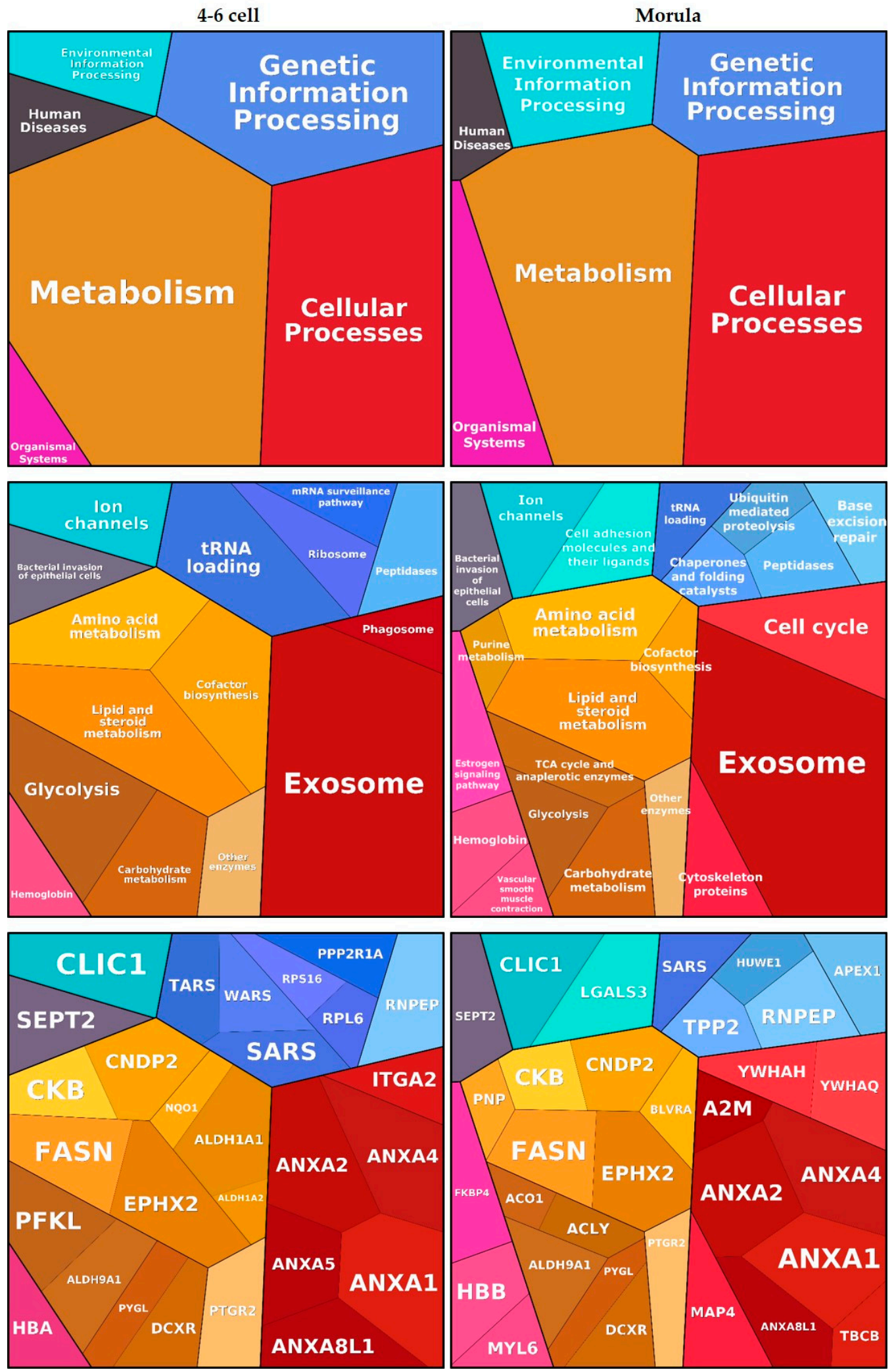

Figure 3. Functions associated with embryo-interacting proteins at the 4-6 cell and morula stages. The figures were automatically built in Proteomaps based on the KEGG (Kyoto Encyclopedia of Genes and Genomes) Pathway gene classification. Functional categories (up and middle panels) and related proteins (down panel) are shown by polygons. Areas of polygons illustrate protein abundance, weighted by protein size. Functionally related function/protein are arranged in common regions and coded using similar colors. 


\subsection{Protein Interactions Were Localized in Different Embryo Subcompartments}

Two highly abundant interacting proteins (OVGP1 and ANXA1) and one among the least abundant ones (PYGL) were chosen to visualize protein interactions in 4-8 cell embryos by immunohistochemistry. The signal for ANXA1 was recorded in the zona pellucida, perivitelline space and into blastomeres of OF-treated embryos (Figure 4a). The pattern of interactions was slightly different for OVGP1 and PYGL, which was localized in the perivitelline space and in blastomeres but not in the zona pellucida of OF-treated embryos (Figure 4c,e, respectively). A negligible diffuse signal was observed in blastomeres of control embryos incubated with primary antibodies against ANXA1, OVGP1 and PYGL (Figure 4b,d,f). No signal was detected in OF-treated and control embryos incubated with IgG isotypes (frames in Figure 4).
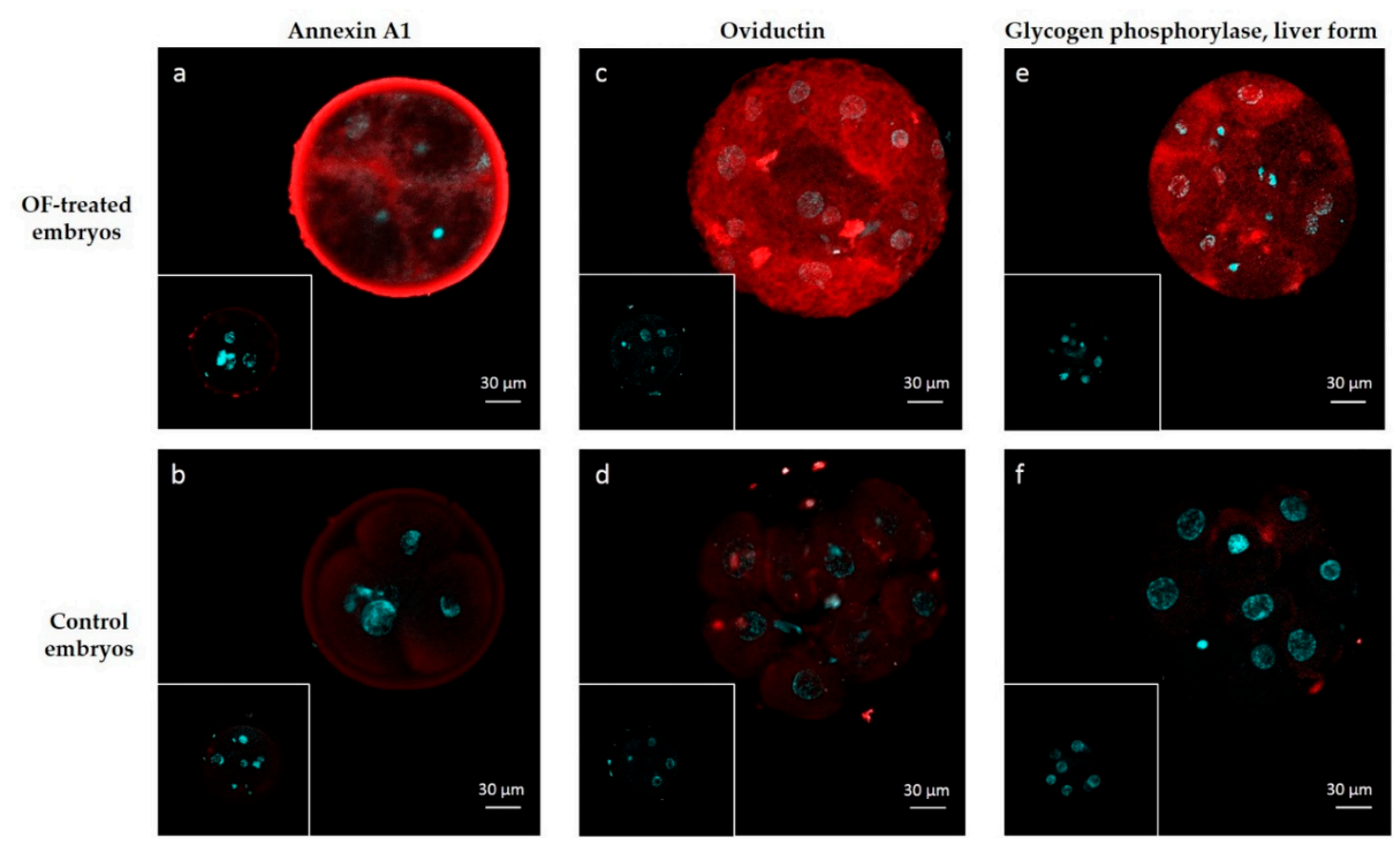

Figure 4. Immunolocalization of embryo-interacting proteins in OF-treated embryos (a,c,e) and controls $(\mathbf{b}, \mathbf{d}, \mathbf{f})$. Proteins of interest are in red and nuclei are in blue. Embryos were incubated with anti-ANXA1 (a,b), anti-OVGP1 (c,d) and anti-PYGL (d,e). Inserts: controls with isotypes instead of primary antibodies.

\section{Discussion}

The bovine embryo develops in contact with the OF for the first 4-5 days of its life. To date, there is limited information regarding the molecular interactions occurring between the embryo and its maternal microenvironment. In this study, using a high-resolution MS technique, a number of new embryo-interacting proteins originated in the OF were identified. To our knowledge, this is the first study providing a significant list of proteins interacting with the early embryo in mammals.

The first criterion retained for the definition of embryo-interacting proteins was their detection in the post-ovulatory OF ipsilateral to ovulation. A total of 1707 proteins were identified by nanoLC-MS/MS in the OF used to produce OF-treated embryos. The most abundant proteins in the OF included serum albumin, heat shock proteins (HSP90AA1, HSP90B1, HSP90AB1, HSPA1B, HSPA5), oviductin (OVGP1), annexin A4 (ANXA4), complement C3 (C3), myosin 9 (MYH9) and numerous tubulin subunits. This is in agreement with previous proteomic analyses of post-ovulatory OF collected from cows at the slaughterhouse [5] or by transvaginal endoscopy [7]. Based on our previous work on the regulation of the bovine OF proteome across the estrous cycle [5], some proteins more abundant in the OF around the time of ovulation compared with 
the luteal phase were identified as embryo-interacting proteins. This is the case, among others, for OVGP1, CD109 and PFKL. Some of these proteins and others were also at higher levels on the side of ovulation, i.e., the side of embryo development, than on the contralateral side at the post-ovulatory stage - this is the case for A2M, CD109 and PFKL [5]. However, at the same stage, EPHX2 was less abundant in the ipsilateral than in the contralateral $\mathrm{OF}$, showing that the secretion of some but not all embryo-interacting proteins may be upregulated at the time and place of embryo presence in the oviduct.

We hypothesized that numerous proteins present in the OF could interact with in vitro- produced early embryos. However, the 56 embryo-interacting proteins accounted for only $0.03 \%$ of the identified OF proteins. To our knowledge, this is the first study deciphering OF embryo-interacting proteins using a MS-based approach with no a priori. In an earlier study using the same methodology on bovine spermatozoa, we identified 27 oviductal proteins that interacted with bovine sperm cells [31]. Similarly, sperm-interacting proteins accounted for less than $0.06 \%$ of proteins previously identified by MS in the OF $[5,31]$. In addition to the low proportion of embryo-interacting proteins among $\mathrm{OF}$ proteins, there was no relationship between the initial abundance of the embryo-interacting proteins in the OF and their abundance in OF-treated embryos. To illustrate this, galectin-3 (LGALS3) was the fifth most abundant embryo-interacting protein in morulas but was detected with low abundance (12 normalized weighted spectra (NWS)) in the OF. On the other hand, PYGL was among the top-50 most abundant proteins (83 NWS) in the OF but one of the least abundant embryo-interacting proteins. Thus, it seems that very few OF proteins interacted with embryos and that these interactions were not related to their initial abundance around embryos, suggesting highly selective and specific embryo-OF interactions. However, we cannot exclude that longer incubation times $(>6 \mathrm{~h})$ may enable more OF proteins to interact. Moreover, this study was carried out on in-vitro produced embryos for obvious economical and ethical reasons (more than 800 embryos were used). Although oviductin is known to interact with bovine embryos in vivo [24] and was identified as interacting proteins under our conditions, it cannot be ruled out that embryo-protein interactions differ in vivo.

Oviductin was identified by nanoLC-MS/MS as interacting in high abundance with both 4-6 cells and morulas and was immunolocalized in the perivitelline space and blastomeres of OF-treated embryos. This is in agreement with previous studies in which OVGP1 was identified by immunostaining and/or western blot in bovine oocytes $[28,29]$ and embryos $[19,24]$ exposed to OF in vivo or in vitro. However, we did not observe a strong signal for OVGP1 in the zona pellucida of OF-treated embryos. Bovine embryos collected in vivo [24] or produced in vitro in the presence of recombinant OVGP1 [19] displayed high immunostaining in the zona pellucida. ANXA1 was observed in the zona pellucida of OF-treated embryos, showing that our conditions did not prevent protein interactions with the zona pellucida. These differences in OVGP1 localization may be due to differences in the origin of embryos used and to the duration of contact with OF or recombinant OVGP1 before immunostaining. A 6-h incubation was used in the present study, whereas embryos were retrieved in vivo after approximately 2 days within the oviduct in the study from Boice et al. [24] or incubated in vitro with recombinant OVGP1 for 3.5 days in the study from Algarra et al. [19]. These differences may also be due to the different antibodies used: a monoclonal antibody raised against the C-terminus of mouse oviductin in the present study vs. a home-made polyclonal antiserum directed against bovine oviduct glycoproteins [24], or a home-made monoclonal antibody directed against purified recombinant porcine OVGP1 [19].

In addition to oviductin, osteopontin (SPP1) and L-PGDS have been reported earlier as oviductal proteins interacting with the zona pellucida of bovine oocytes [29]. However, in this study, SPP1 and L-PGDS were not identified in the OF used for embryo incubation, and therefore could not be identified as interacting proteins. In line with our results, SPP1 and L-PGDS were not identified in previous MS-based analyses of bovine OF, either throughout the estrous cycle [5] or at Days 1 and 3 of the estrous cycle [7], both studies identifying more than 3000 proteins. Thus, the presence of SPP1 and L-PGDS in the bovine OF and their potential interaction with the bovine embryo cannot be confirmed. Moreover, inactivated complement-3b (iC3b), a derivative of the human complement protein $\mathrm{C} 3$ (C3), 
was shown to be taken up by mouse embryos, resulting in an increase in embryo development up to the blastocyst stage [32]. In the present study, C3 was identified at high abundance in the post-ovulatory OF (113 NWS, Table S1). However, C3 was not identified as interacting with cattle embryos. Therefore, some oviductal protein interactions with embryo are likely to be species-specific.

There is some evidence that the developing embryo interacts with its oviductal microenvironment $[13,33,34]$. However, little is known about the modulating role played by the embryo in these interactions. In order to address this question, the same $\mathrm{OF}$ and conditions of embryo incubation were used for both 4-6 cells and morulas. The results showed that 13 OF proteins interacted exclusively with 4-6 cell embryos, while 19 interacted only with morulas. Furthermore, for some proteins interacting at both stages, their abundance in OF-treated embryos differed between stages. For instance, the fold-change between OF-treated and control embryos for ANXA1 was approximately twice higher in 4-6 cells than in morulas ( 37 vs. 15). This suggests a modulating role played by the zona pellucida and/or embryonic cells in the process of protein interaction. The zona pellucida surrounding all mammalian embryos constitutes the first barrier for interactions between OF protein and embryonic cells. Several studies indicated that the zona pellucida is a dynamic envelope that changes in structure and properties depending on its environment [35-37]. The zona pellucida of mouse oocytes were shown to be permeable to macromolecules at molecular weights up to $170 \mathrm{kDa}$, while zygotes showed a decreased permeability at around $110 \mathrm{kDa}$ [37]. Using colored molecular probes, it was shown that the size and hydrophilic-lipophilic balance of the probe were important in determining its interaction with the mouse embryo [36]. Scanning electron microscopy observation of bovine in vitro-produced embryos showed that the outer zona pellucida surface typically forms a spongy network with a rough surface containing numerous pores; however, the mean number of pores doubled from the 8-cell to the morula stages (1658 vs. 3259 per $\left.5000 \mu \mathrm{m}^{2}\right)$ and their mean diameter decreased in parallel (203 vs. $155 \mathrm{~nm}$ ) [35]. These changes may contribute to the observed stage-specific embryo-protein interactions. Furthermore, the 8-cell stage was identified as the period of major embryonic genome activation in the bovine embryo [3,38]. At this time, maternal RNAs and proteins stored in the oocyte are gradually degraded and actively replaced by embryonic transcripts and proteins [3]. Therefore, molecules and interaction processes at the embryonic cell surface are likely to change from 4-6 cell to morula and to contribute, in association with changes in the zona pellucida permeability, to the differences in $\mathrm{OF}$ protein interactions between embryonic stages.

Oviductal EVs comprise exosomes, which are small 30-150 nm vesicles endocytic in origin and released upon fusion of multi-vesicular bodies with the membrane of oviduct epithelial cells, and microvesicles, which are larger vesicles (100-1000 nm) budding directly from the cell membrane [8]. The proteomic contents of oviductal EVs were recently published in the bovine [9] and feline [30], with many more proteins identified in the latter (1511 vs. 319 protein groups). Therefore, both species were considered to analyze potential secretion pathways of interacting proteins. In the present study, only five embryo-interacting proteins $(9 \%)$ contained a signal peptide and appeared likely to be secreted in a classical way, whereas the majority of proteins were presumed to be secreted by non-conventional pathways and/or previously reported in oviductal EVs, including OVGP1, several annexins (A1, A2, A4, A5) and the liver form of glycogen phosphorylase (PYGL). It is important to note that these secretion pathways are not exclusive-interacting proteins like OVGP1, CD109 and alpha-2 macroglobuline (A2M) possess a signal peptide but were also identified in oviductal EVs. Furthermore, in the present study, OVGP1, ANXA1 and PYGL were immunolocalized in the perivitelline space but also in blastomeres of OF-treated embryos, showing that these molecules crossed the zona pellucida and were internalized by embryonic cells. To our knowledge, this is the first report of immunolocalization of ANXA1 and PYGL in mammalian embryos. Bovine embryos were shown to be able to internalize PKH67-labelled in vivo-derived oviductal EVs during in vitro development [9]. Cloned and parthenogenic porcine embryos were also able to uptake embryo-derived membrane-labelled EVs from the culture medium [39]. In both studies, oviductal EVs were observed in the whole cytoplasm of blastomeres [9,39]. Using electron microscopy on 2- to 8-cell embryos collected from hamster oviducts, endocytic structures, 
many endosomes and multivesicular bodies associated with OVGP1 immunolabeling were observed in the blastomeres [26]. Taken together, these results strongly suggest that oviductal proteins previously reported as exosomal were internalized into OF-treated embryos via exosomal cargos. However, the exact mechanisms by which OF proteins interacted with embryonic cells were beyond the scope of this study and remain to be determined.

Cattle embryos enter the uterus at the early morula stage and have a long pre-implantation period during which blastocyst hatching (Days 9-10), trophoblast elongation and intense production of interferon-tau (IFNT) occur before implantation begins, around Day 19 of pregnancy [2]. The possible functions of oviductal interacting proteins on pre-implantation steps are poorly understood. Some roles played by oviductin on early embryo development were reported from in vitro studies. Consistent positive effects of purified oviductin were observed on blastocyst yield in goat [17], sheep [40], pig [41] and cattle [18]. Antibodies directed against the C-terminal peptide of rabbit oviductin were shown to inhibit mouse embryo development at the 2-cell stage, suggesting that in this species, oviductin has a function in overcoming the development block at this stage [42]. In bovine, the addition of porcine recombinant oviductin during in vitro fertilization, in vitro development or both, increased the relative abundance in the embryo of mRNA of DSC2, ATF4, AQP3 and DNMT3A, genes involved in cell proliferation, cell adhesion, cellular homeostasis and epigenetics [19].

Four annexins, namely ANXA1, ANXA2, ANXA4 and ANXA5, were identified as embryo-interacting proteins, only at the 4-6-cell stage for ANXA5 and at both stages for ANXA1, ANXA2 and ANXA4. It is well established that some annexins, including ANXA1 and ANXA2, can be secreted out of the cell through unconventional secretory mechanisms, with implications in many functions such as the endocrine regulation, inflammatory response and cancer [43]. Several studies have associated annexins with early embryo-maternal interactions. A greater abundance of ANXA4 was reported in the OF of pregnant mares compared with cyclic mares four days after ovulation [44] and both ANXA1 and ANXA2 were increased in the uterine fluid around the signaling of maternal recognition in this species [45]. Similarly, increasing amounts of ANXA1, ANXA2 and ANXA5 were reported in the uterine fluid of pregnant ewes in the pre-implantation period [45]. Annexin A1 knock-out female mice displayed numerous changes in early gestation, including increased sites of implantation, increased inflammatory reaction in the uterine fluid during implantation, reduced pre- and post-implantation losses and enhanced plasma progesterone [46]. Furthermore, ANXA2 was shown to be crucial for embryo adhesiveness to the endometrium, a critical step for implantation, in humans [47] and mice [48].

Galectin-3 and -9 interacted only with morulas and galectin-3 was one of the most abundant interacting proteins at this stage. Galectins have a varied array of activities both inside and outside cells [49]. Galectin-3 and -9 are members of the lectin family and contain carbohydrate recognition domains [49]. Galectin-3 is expressed in several parts of the female genital tract, including the uterine endometrium and oviduct [50,51]. When galectin-3 was knocked down in the mouse endometrium, the number of embryos implanted decreased substantially [51], showing that, like annexins, galectins have important roles in the establishment of pregnancy in mice.

In conclusion, proteins in the post-ovulatory OF that interact with the early bovine embryo before and after the embryonic genome activation were identified and quantified on a large scale for the first time. Some protein interactions were developmental stage-specific, revealing new roles of the embryo in modulating early maternal interactions. These data provide new protein candidates potentially involved in pre-implantation development and establishment of pregnancy in cattle. Targeted studies are required to go further in the search for underlying mechanisms and functions.

\section{Materials and Methods}

All reagents were purchased from Sigma-Merck (Saint-Louis, MO, USA) if not otherwise stated. PMSG, hCG and PG-600 were obtained from MSD Animal Health (Brussels, Belgium). Bovine trypsin was obtained from Roche Diagnostics GmbH (Basel, Switzerland). Paraformaldehyde (sc-281692) and mouse monoclonal antibodies raised against OVGP1 (sc-377267) and PYGL (sc-517597) were obtained 
from Santa-Cruz Biotechnology (Dallas, TX, USA). Goat polyclonal antibody raised against ANXA1 (AP22515PU-N) was obtained from Origene (Rockville, MD, USA). Secondary antibodies coupled with Alexa Fluor 633 (A21050 for ANXA1; A21082 for OVGP1 and PYGL) were obtained from Invitrogen Molecular Probes (Eugene, OR, USA).

\subsection{Bovine Oviductal Fluid (OF) Collection}

Oviducts connected to ovaries from adult Bos taurus cows were collected at a slaughterhouse and transported to the laboratory on ice within $2 \mathrm{~h}$ after the death of the animal. According to the morphology of the ovary and corpus luteum, only oviducts ipsilateral to the side of ovulation at the post-ovulatory phase of the estrous cycle (Days 1-5, i.e., at the expected time and place of embryo development) were used. Mixtures of $\mathrm{OF}$ and epithelial cells were collected from the whole oviducts by gentle squeezing, then the $\mathrm{OF}$ was isolated by two centrifugations $(2000 \times \mathrm{g}, 15 \mathrm{~min}$ then $12,000 \times \mathrm{g}, 10 \mathrm{~min})$ at $4{ }^{\circ} \mathrm{C}$. The $\mathrm{OF}$ from 22 cows were pooled, assayed for protein concentration, divided into $15-\mu \mathrm{L}$ aliquots and stored at $-80^{\circ} \mathrm{C}$ before used for incubation with embryos. The same pool of post-ovulatory OF was used for all embryo co-incubations.

\subsection{Embryo In-Vitro Production and Incubation with OF}

Bovine ovaries were collected from a local slaughterhouse and transported at $36{ }^{\circ} \mathrm{C}$ to the laboratory. Cumulus-oocyte complexes (COCs) were recovered using HEPES-buffered TCM-199 supplemented with $0.4 \mathrm{~g} / \mathrm{L}$ bovine serum albumin (BSA) and $0.25 \%$ gentamicin. Groups of 30-60 COCs were matured in TCM-199 supplemented with $10 \mathrm{ng} / \mathrm{mL}$ EGF, $19 \mathrm{ng} / \mathrm{mL}$ IGF-1, $2.2 \mathrm{ng} / \mathrm{mL}$ FGF, $5 \mathrm{UI} / \mathrm{mL}$ hCG, $10 \mathrm{UI} / \mathrm{mL}$ PMSG, $4 \mu \mathrm{g} / \mathrm{mL}$ transferrin, $4 \mu \mathrm{g} / \mathrm{mL}$ insulin, $5 \mathrm{ng} / \mathrm{mL}$ sodium selenite, $1 \%$ PG-600, $90 \mu \mathrm{g} / \mathrm{mL}$ L-cysteine, $0.1 \mathrm{mM}$ beta-mercaptoethanol, $75 \mu \mathrm{g} / \mathrm{mL}$ ascorbic acid, $720 \mu \mathrm{g} / \mathrm{mL}$ glycine, $0.1 \mathrm{mg} / \mathrm{mL}$ glutamine and $110 \mu \mathrm{g} / \mathrm{mL}$ pyruvate at $38.8^{\circ} \mathrm{C}(5 \% \mathrm{CO} 2)$ for $22 \mathrm{~h}$. After maturation, COCs (50 per well) were transferred in $250 \mu \mathrm{L}$ of fertilization medium (Tyrode medium supplemented with $25 \mathrm{mM}$ bicarbonate, $10 \mathrm{mM}$ lactate, $1 \mathrm{mM}$ pyruvate, $6 \mathrm{mg} / \mathrm{mL}$ fatty-acid free BSA, $10 \mu \mathrm{g} / \mathrm{mL}$ heparin and $40 \mu \mathrm{g} / \mathrm{mL}$ gentamycin). Motile spermatozoa were recovered by Percoll washing from one Normande bull (Evolution, Noyal-sur-Vilaine, France) and added to the fertilization medium (Day 0) at a final concentration of $10^{6}$ spermatozoa/mL for $22 \mathrm{~h}$. At Day 1, all presumptive zygotes were cultured in $25 \mu \mathrm{L}$ of synthetic oviductal fluid (SOF) medium [52] supplemented with $0.01 \%$ of polyvinyl alcohol (SOF-PVA) without any serum or protein supplementation, under mineral oil (M8410) at $38.8^{\circ} \mathrm{C}$ with $5 \% \mathrm{CO}_{2}$ and $5 \% \mathrm{O}_{2}$. At Days 3 and 5, groups of 50 embryos of normal morphology (spherical embryos with blastomeres uniform in size, color and density) at the 4-6 cell and morula stages, respectively, were randomly allocated to incubation in $30 \mu \mathrm{L}$ of OF at a final protein concentration of $37 \mathrm{mg} / \mathrm{mL}$ (OF-treated embryos) or in $30 \mu \mathrm{L}$ of SOF-PVA (controls) for $6 \mathrm{~h}$ at $38.8{ }^{\circ} \mathrm{C}$ with $5 \% \mathrm{CO}_{2}$ and $5 \% \mathrm{O}_{2}$. After incubation, all embryos were washed three times in $20 \mathrm{mM}$ Tris- $\mathrm{HCl}$ buffer ( $\mathrm{pH} 6.8$ ) supplemented with $8.9 \%$ sucrose (Tris-sucrose). Then, pools of 25 embryos were stored in $1.5-\mathrm{mL}$ tubes at $-80{ }^{\circ} \mathrm{C}$ for proteomics analysis. Four biological replicates were produced for $4-6$ cells and morulas, i.e., 400 embryos for each stage (200 OF-treated and 200 controls).

\subsection{Nanoliquid Chromatography Coupled with Tandem Mass Spectrometry (NanoLC-MS/MS)}

For proteomics, pools of 25 embryos (OF-treated and controls) and one aliquot of OF were lysed in a $10 \mathrm{mM}$ Trizma ${ }^{\circledR}$ base supplemented with $4 \%$ sodium dodecyl sulfate (SDS) and $0.05 \%$ of a protease inhibitor cocktail for $15 \mathrm{~min}$ at ambient temperature. Protein concentrations were determined using a Nanodrop 2000/2000c ${ }^{\circledR}$ (Thermo Scientific, Waltham, MA, USA). The samples were incubated for $5 \mathrm{~min}$ at $95^{\circ} \mathrm{C}$ in Laemmli Buffer then protein lysates $(4 \mu \mathrm{g}$ for $4-6$ cells, $6 \mu \mathrm{g}$ for morulas, $15 \mu \mathrm{g}$ for the OF) were briefly migrated on a home-made 0.75 -mm thick $10 \%$ SDS-PAGE $(50 \mathrm{~V}, 15 \mathrm{~min})$ to get one band per sample. The gel bands were stained with BluePage ${ }^{\circledR}$ overnight then proteins were in-gel digested with bovine trypsin, as previously described [5]. Salts were removed from samples using C18 SpinColumns (Harvard Apparatus, Les Ulis, France). The resulting peptide mixtures were separated 
on a $75 \mu \mathrm{m} \times 250 \mathrm{~mm}$ IonOpticks Aurora $2 \mathrm{C} 18$ column (Ion Opticks Pty Ltd., Bundoora, Australia). A gradient of basic reversed-phase buffers (Buffer A: 0.1\% formic acid, $98 \% \mathrm{H}_{2} \mathrm{O}$ MilliQ, $2 \%$ acetonitrile; Buffer B: $0.1 \%$ formic acid, $100 \%$ acetonitrile) was run on a NanoElute HPLC System (Bruker Daltonik $\mathrm{GmbH}$, Bremen, Germany) at a flow rate of $400 \mathrm{~nL} / \mathrm{min}$ at $50{ }^{\circ} \mathrm{C}$. The liquid chromatography (LC) run lasted for $120 \mathrm{~min}$ (2\% to $15 \%$ of buffer B during $60 \mathrm{~min}$; up to $25 \%$ at $90 \mathrm{~min}$; up to $37 \%$ at $100 \mathrm{~min}$; up to $95 \%$ at $110 \mathrm{~min}$ and finally $95 \%$ for $10 \mathrm{~min}$ to wash the column). The column was coupled online to a TIMS TOF Pro (Bruker Daltonik GmbH, Bremen, Germany) with a CaptiveSpray ion source (Bruker Daltonik). The temperature of the ion transfer capillary was set at $180^{\circ} \mathrm{C}$. Ions were accumulated for $114 \mathrm{~ms}$, and mobility separation was achieved by ramping the entrance potential from $-160 \mathrm{~V}$ to $-20 \mathrm{~V}$ within $114 \mathrm{~ms}$. The acquisition of the MS and MS/MS mass spectra was done with average resolutions of 60,000 and 50,000 full width at half maximum (mass range 100-1700 m/z), respectively. To enable the PASEF method, precursor $\mathrm{m} / \mathrm{z}$ and mobility information was first derived from full scan TIMS-MS experiments (with a mass range of $m / z$ 100-1700). The quadrupole isolation width was set to 2 and $3 \mathrm{Th}$ and, for fragmentation, the collision energies varied between 31 and $52 \mathrm{eV}$ depending on the precursor mass and charge. TIMS, MS operation and PASEF were controlled and synchronized using the control instrument software OtofControl 5.1 (Bruker Daltonik). LC-MS/MS data were acquired using the PASEF method with a total cycle time of $1.31 \mathrm{~s}$, including 1 TIMS MS scan and 10 PASEF MS/MA scans. The 10 PASEF scans (100 ms each) containing, on average, $12 \mathrm{MS} / \mathrm{MS}$ scans per PASEF scan. Ion mobility-resolved mass spectra, nested ion mobility vs. $m / z$ distributions, as well as summed fragment ion intensities were extracted from the raw data file with DataAnalysis 5.1 (Bruker Daltonik $\mathrm{GmbH}$, Bremen, Germany).

\subsection{Quantification of Proteins, Identification of Embryo-Interacting Proteins and Statistical Analysis}

All proteins with more than two peptides identified were considered for protein quantification. Protein quantification was based on a label-free approach using spectral counting, as previously described [31]. Scaffold Q+ software (version 4.9, Proteome Software; www.proteomesoftware.com) was used using the Spectral Count quantitative module. Peptide identifications were accepted if they could be established with greater than $95.0 \%$ probability as specified by the Peptide Prophet algorithm [53]. Peptides were considered distinct if they differed in sequence. Protein identifications were accepted if they could be established with greater than $95.0 \%$ probability as specified by the Protein Prophet algorithm [54] and contained at least two identified peptides (false discovery rate $($ FDR $)<0.01 \%)$.

The normalization of spectra among the samples was realized in Scaffold by adjusting the sum of the selected quantitative values for all proteins within each MS sample to a common value, which was the average of the sums of all MS samples present in the experiment. This was achieved by applying a scaling factor for each sample to each protein or protein group. Thus, the numbers of the normalized weighted spectra (NWS) were tabulated using experiment-wide protein clusters.

Proteins were defined as embryo-interacting proteins originating in the $\mathrm{OF}$ if they met the following conditions: (i) detection at a minimum level of 5 NWS in the OF and (ii) detection at a minimum level of $5 \mathrm{NWS}$ in OF-treated embryos with no detection in controls or significantly higher detection in OF-treated embryos than in controls after Student's t-test with Benjamini-Hochberg correction $(p$-value $<0.05$; fold-change $>2$ ).

\subsection{Functional Analyses of Interacting Proteins}

To predict the secretion ways of embryo-interacting proteins, the online tools SignalP 5.0 (http: //www.cbs.dtu.dk/services/SignalP/) and SecretomeP 2.0 (http://www.cbs.dtu.dk/services/SecretomeP/) were used. Proteins predicted as possessing a standard secretory signal peptide and a peptide cleavage site in their N-terminal sequence were considered as secreted in a conventional way. In addition, proteins predicted as being targeted to a non-classical pathway in the mammalian dataset of SecretomeP were considered as potentially undergoing non-conventional secretion. A cutoff $\mathrm{NN}$-score value of 
0.6 was applied. To go further in the non-conventional secretion pathway, we looked for the presence of the protein among those reported in bovine [9] and feline [30] oviductal EVs. The online tool Proteomaps 2.0 (https://bionic-vis.biologie.uni-greifswald.de) was used for the functional annotation of embryo-interacting proteins using NWS values and Gene IDs of interacting proteins, and the Bos taurus dataset.

\subsection{Immunolocalization of ANXA1, OVGP1 and PYGL}

By western blotting, the primary antibodies used gave one band at the expected molecular weight in bovine post-ovulatory oviduct epithelial cells and OF (Figure S2). For immunostaining, embryos of normal morphology at Day 3 were used. Embryos were incubated or not (controls) in OF and washed in Tris-sucrose as described above. Embryos were then fixed for $30 \mathrm{~min}$ in $4 \%$ paraformaldehyde at $35^{\circ} \mathrm{C}$ then washed three times in PBS supplemented with $0.1 \%(w / v)$ BSA (PBS-BSA). For blocking, embryos were incubated for $40 \mathrm{~min}$ at ambient temperature in PBS-BSA supplemented with $10 \%(v / v)$ serum from the same host species as the secondary antibody (donkey for OVGP1 and PYGL; goat for ANXA1). After three washings in PBS-BSA, the embryos were incubated overnight at $4{ }^{\circ} \mathrm{C}$ with either anti-ANXA1, anti-OVGP1 (both at $1 \mu \mathrm{g} / \mathrm{mL}$ ) or anti-PYGL (at $0.5 \mu \mathrm{g} / \mathrm{mL}$ ) diluted in PBS-PSA. Isotypes at the same concentrations were used as negative controls. After two washings in PBS-BSA, embryos were incubated overnight at $4{ }^{\circ} \mathrm{C}$ in the secondary antibody diluted at $1 / 1000$ in PBS-BSA. At the end of incubation, Hoechst 33,342 was added $(10 \mu \mathrm{g} / \mathrm{mL}, 10 \mathrm{~min})$ for nucleus staining. After three washings in PBS-BSA, embryos were mounted in PBS-BSA and immediately observed under confocal microscopy (Zeiss LSM 700, Carl Zeiss, Oberkochen, Germany). Two biological replicates were made for each antibody.

Supplementary Materials: Supplementary Materials can be found at http://www.mdpi.com/1422-0067/21/2/466/s1.

Author Contributions: Conceptualization, M.S.-D. and P.M.; methodology, C.B., V.L., A.-P.T.-G., C.P., E.C., R.L., G.T.; software, C.B. and E.C.; validation, C.B.; formal analysis, C.B.; resources, M.S.-D. and B.G.; writing-original draft preparation, C.B. and M.S.-D.; writing-review and editing, all authors; supervision, M.S.-D.; project administration, M.S.-D. and B.G.; funding acquisition, B.G. All authors have read and agreed to the published version of the manuscript.

Funding: This research was funded by Evolution and INRA. Charles Banliat was funded by ANRT, grant number 2017/0684. This work was also supported by grants from Biogenouest, Infrastructures en Biologie Santé et Agronomie (IBiSA) and Conseil Régional de Bretagne awarded to Charles Pineau.

Acknowledgments: The authors are grateful to Marc Chodkievicz for editing this manuscript, and to Thierry Delpuech and Albert Arnould for the collection of ovaries and oviducts. The authors thank Evolution for providing the bull semen. M.S.D. thanks the CNRS for hosting her on delegation.

Conflicts of Interest: The authors declare no conflict of interest. The funders had no role in the design of the study; in the collection, analyses, or interpretation of data; in the writing of the manuscript, or in the decision to publish the results.

\section{Abbreviations}

$\begin{array}{ll}\text { OF } & \text { Oviductal fluid } \\ \text { EV } & \text { Extracellular vesicles } \\ \text { MS } & \text { Mass spectrometry } \\ \text { nanoLC-MS/MS } & \text { Nanoliquid chromatography coupled with tandem mass spectrometry } \\ \text { NWS } & \text { Normalized weighted spectra }\end{array}$

\section{References}

1. Kolle, S.; Dubielzig, S.; Reese, S.; Wehrend, A.; Konig, P.; Kummer, W. Ciliary transport, gamete interaction, and effects of the early embryo in the oviduct: Ex vivo analyses using a new digital videomicroscopic system in the cow. Biol. Reprod. 2009, 81, 267-274. [CrossRef]

2. Lonergan, P.; Forde, N. Maternal-embryo interaction leading up to the initiation of implantation of pregnancy in cattle. Animal 2014, 8 (Suppl. 1), 64-69. [CrossRef] 
3. Graf, A.; Krebs, S.; Heininen-Brown, M.; Zakhartchenko, V.; Blum, H.; Wolf, E. Genome activation in bovine embryos: Review of the literature and new insights from RNA sequencing experiments. Anim. Reprod. Sci. 2014, 149, 46-58. [CrossRef]

4. Leese, H.J.; Hugentobler, S.A.; Gray, S.M.; Morris, D.G.; Sturmey, R.G.; Whitear, S.L.; Sreenan, J.M. Female reproductive tract fluids: Composition, mechanism of formation and potential role in the developmental origins of health and disease. Reprod. Fertil. Dev. 2008, 20,1-8. [CrossRef] [PubMed]

5. Lamy, J.; Labas, V.; Harichaux, G.; Tsikis, G.; Mermillod, P.; Saint-Dizier, M. Regulation of the bovine oviductal fluid proteome. Reproduction 2016, 152, 629-644. [CrossRef]

6. Pillai, V.V.; Weber, D.M.; Phinney, B.S.; Selvaraj, V. Profiling of proteins secreted in the bovine oviduct reveals diverse functions of this luminal microenvironment. PLoS ONE 2017, 12, e0188105. [CrossRef] [PubMed]

7. Papp, S.M.; Frohlich, T.; Radefeld, K.; Havlicek, V.; Kosters, M.; Yu, H.; Mayrhofer, C.; Brem, G.; Arnold, G.J.; Besenfelder, U. A novel approach to study the bovine oviductal fluid proteome using transvaginal endoscopy. Theriogenology 2019, 132, 53-61. [CrossRef] [PubMed]

8. Alminana, C.; Bauersachs, S. Extracellular vesicles in the oviduct: Progress, challenges and implications for the reproductive success. Bioengineering 2019, 6, 32. [CrossRef] [PubMed]

9. Alminana, C.; Corbin, E.; Tsikis, G.; Alcantara-Neto, A.S.; Labas, V.; Reynaud, K.; Galio, L.; Uzbekov, R.; Garanina, A.S.; Druart, X.; et al. Oviduct extracellular vesicles protein content and their role during oviduct-embryo cross-talk. Reproduction 2017, 154, 153-168. [CrossRef] [PubMed]

10. Alminana, C.; Tsikis, G.; Labas, V.; Uzbekov, R.; da Silveira, J.C.; Bauersachs, S.; Mermillod, P. Deciphering the oviductal extracellular vesicles content across the estrous cycle: Implications for the gametes-oviduct interactions and the environment of the potential embryo. BMC Genom. 2018, 19, 622. [CrossRef]

11. Fair, T.; Lonergan, P.; Dinnyes, A.; Cottell, D.C.; Hyttel, P.; Ward, F.A.; Boland, M.P. Ultrastructure of bovine blastocysts following cryopreservation: Effect of method of blastocyst production. Mol. Reprod. Dev. 2001, 58, 186-195. [CrossRef]

12. Rizos, D.; Clemente, M.; Bermejo-Alvarez, P.; de La Fuente, J.; Lonergan, P.; Gutierrez-Adan, A. Consequences of in vitro culture conditions on embryo development and quality. Reprod. Domest. Anim. 2008, 43 (Suppl. 4), 44-50. [CrossRef]

13. Maillo, V.; Lopera-Vasquez, R.; Hamdi, M.; Gutierrez-Adan, A.; Lonergan, P.; Rizos, D. Maternal-embryo interaction in the bovine oviduct: Evidence from in vivo and in vitro studies. Theriogenology 2016, 86, 443-450. [CrossRef] [PubMed]

14. Lopera-Vasquez, R.; Hamdi, M.; Maillo, V.; Lloreda, V.; Coy, P.; Gutierrez-Adan, A.; Bermejo-Alvarez, P.; Rizos, D. Effect of bovine oviductal fluid on development and quality of bovine embryos produced in vitro. Reprod. Fertil. Dev. 2015. [CrossRef] [PubMed]

15. Hamdi, M.; Lopera-Vasquez, R.; Maillo, V.; Sanchez-Calabuig, M.J.; Nunez, C.; Gutierrez-Adan, A.; Rizos, D. Bovine oviductal and uterine fluid support in vitro embryo development. Reprod. Fertil. Dev. 2017. [CrossRef]

16. Lopera-Vasquez, R.; Hamdi, M.; Maillo, V.; Gutierrez-Adan, A.; Bermejo-Alvarez, P.; Ramirez, M.A.; Yanez-Mo, M.; Rizos, D. Effect of bovine oviductal extracellular vesicles on embryo development and quality in vitro. Reproduction 2017, 153, 461-470. [CrossRef] [PubMed]

17. Pradeep, M.A.; Jagadeesh, J.; De, A.K.; Kaushik, J.K.; Malakar, D.; Kumar, S.; Dang, A.K.; Das, S.K.; Mohanty, A.K. Purification, sequence characterization and effect of goat oviduct-specific glycoprotein on in vitro embryo development. Theriogenology 2011, 75, 1005-1015. [CrossRef] [PubMed]

18. Choudhary, S.; Kumaresan, A.; Kumar, M.; Chhillar, S.; Malik, H.; Kumar, S.; Kaushik, J.K.; Datta, T.K.; Mohanty, A.K. Effect of recombinant and native buffalo OVGP1 on sperm functions and in vitro embryo development: A comparative study. J. Anim. Sci. Biotechnol. 2017, 8, 69. [CrossRef]

19. Algarra, B.; Maillo, V.; Aviles, M.; Gutierrez-Adan, A.; Rizos, D.; Jimenez-Movilla, M. Effects of recombinant OVGP1 protein on in vitro bovine embryo development. J. Reprod. Dev. 2018, 64, 433-443. [CrossRef]

20. Malette, B.; Bleau, G. Biochemical characterization of hamster oviductin as a sulphated zona pellucida-binding glycoprotein. Biochem. J. 1993, 295, 437-445. [CrossRef]

21. O'Day-Bowman, M.B.; Mavrogianis, P.A.; Minshall, R.D.; Verhage, H.G. In vivo versus in vitro oviductal glycoprotein (OGP) association with the zona pellucida (ZP) in the hamster and baboon. Mol. Reprod. Dev. 2002, 62, 248-256. [CrossRef] [PubMed] 
22. Boice, M.L.; McCarthy, T.J.; Mavrogianis, P.A.; Fazlebas, A.T.; Verhage, H.G. Localization of oviductal glycoproteins within the zona pellucida and perivitelline space of ovulated ova and early embryos in baboons (Papio anubis). Biol. Reprod. 1990, 43, 340-346. [CrossRef] [PubMed]

23. Buhi, W.C.; O’Brien, B.; Alvarez, I.M.; Erdos, G.; Dubois, D. Immunogold localization of porcine oviductal secretory proteins within the zona pellucida, perivitelline space, and plasma membrane of oviductal and uterine oocytes and early embryos. Biol. Reprod. 1993, 48, 1274-1283. [CrossRef] [PubMed]

24. Boice, M.L.; Mavrogianis, P.A.; Murphy, C.N.; Prather, R.S.; Day, B.N. Immunocytochemical analysis of the association of bovine oviduct-specific glycoproteins with early embryos. J. Exp. Zool. 1992, 263, 225-229. [CrossRef] [PubMed]

25. Wegner, C.C.; Killian, G.J. In vitro and in vivo association of an oviduct estrus-associated protein with bovine zona pellucida. Mol. Reprod. Dev. 1991, 29, 77-84. [CrossRef]

26. Kan, F.W.; Roux, E.; Bleau, G. Immunolocalization of oviductin in endocytic compartments in the blastomeres of developing embryos in the golden hamster. Biol. Reprod. 1993, 48, 77-88. [CrossRef]

27. Buhi, W.C. Characterization and biological roles of oviduct-specific, oestrogen-dependent glycoprotein. Reproduction 2002, 123, 355-362. [CrossRef]

28. Staros, A.L.; Killian, G.J. In vitro association of six oviductal fluid proteins with the bovine zona pellucida. J. Reprod. Fertil. 1998, 112, 131-137. [CrossRef]

29. Goncalves, R.F.; Staros, A.L.; Killian, G.J. Oviductal fluid proteins associated with the bovine zona pellucida and the effect on in vitro sperm-egg binding, fertilization and embryo development. Reprod. Domest. Anim. 2008, 43, 720-729. [CrossRef]

30. Ferraz, M.; Carothers, A.; Dahal, R.; Noonan, M.J.; Songsasen, N. Oviductal extracellular vesicles interact with the spermatozoon's head and mid-piece and improves its motility and fertilizing ability in the domestic cat. Sci. Rep. 2019, 9, 9484. [CrossRef]

31. Lamy, J.; Nogues, P.; Combes-Soia, L.; Tsikis, G.; Labas, V.; Mermillod, P.; Druart, X.; Saint-Dizier, M. Identification by proteomics of oviductal sperm-interacting proteins. Reproduction 2018. [CrossRef] [PubMed]

32. Tse, P.K.; Lee, Y.L.; Chow, W.N.; Luk, J.M.; Lee, K.F.; Yeung, W.S. Preimplantation embryos cooperate with oviductal cells to produce embryotrophic inactivated complement-3b. Endocrinology 2008, 149, 1268-1276. [CrossRef] [PubMed]

33. Maillo, V.; Gaora, P.O.; Forde, N.; Besenfelder, U.; Havlicek, V.; Burns, G.W.; Spencer, T.E.; Gutierrez-Adan, A.; Lonergan, P.; Rizos, D. Oviduct-embryo interactions in cattle: Two-way traffic or a one-way street? Biol. Reprod. 2015, 92, 144. [CrossRef] [PubMed]

34. Ghersevich, S.; Massa, E.; Zumoffen, C. Oviductal secretion and gamete interaction. Reproduction 2015, 149, R1-R14. [CrossRef]

35. Vanroose, G.; Nauwynck, H.; Soom, A.V.; Ysebaert, M.T.; Charlier, G.; Oostveldt, P.V.; de Kruif, A. Structural aspects of the zona pellucida of in vitro-produced bovine embryos: A scanning electron and confocal laser scanning microscopic study. Biol. Reprod. 2000, 62, 463-469. [CrossRef]

36. Turner, K.; Horobin, R.W. Permeability of the mouse zona pellucida: A structure-staining-correlation model using coloured probes. J. Reprod. Fertil. 1997, 111, 259-265. [CrossRef]

37. Legge, M. Oocyte and zygote zona pellucida permeability to macromolecules. J. Exp. Zool. 1995, 271, 145-150. [CrossRef]

38. Graf, A.; Krebs, S.; Zakhartchenko, V.; Schwalb, B.; Blum, H.; Wolf, E. Fine mapping of genome activation in bovine embryos by RNA sequencing. Proc. Natl. Acad. Sci. USA 2014, 111, 4139-4144. [CrossRef]

39. Saadeldin, I.M.; Kim, S.J.; Choi, Y.B.; Lee, B.C. Improvement of cloned embryos development by co-culturing with parthenotes: A possible role of exosomes/microvesicles for embryos paracrine communication. Cell. Reprogram. 2014, 16, 223-234. [CrossRef]

40. Nancarrow, C.D.; Hill, J.L. Oviduct proteins in fertilization and early embryo development. J. Reprod. Fertil. Suppl. 1995, 49, 3-13. [CrossRef]

41. Kouba, A.J.; Abeydeera, L.R.; Alvarez, I.M.; Day, B.N.; Buhi, W.C. Effects of the porcine oviduct-specific glycoprotein on fertilization, polyspermy, and embryonic development in vitro. Biol. Reprod. 2000, 63, 242-250. [CrossRef] [PubMed]

42. Yong, P.; Gu, Z.; Luo, J.P.; Wang, J.R.; Tso, J.K. Antibodies against the C-terminal peptide of rabbit oviductin inhibit mouse early embryo development to pass 2-cell stage. Cell Res. 2002, 12, 69-78. [CrossRef] [PubMed] 
43. Sheikh, M.H.; Solito, E. Annexin A1: Uncovering the many talents of an old protein. Int. J. Mol. Sci. 2018, 19, 1045. [CrossRef] [PubMed]

44. Smits, K.; Nelis, H.; Van Steendam, K.; Govaere, J.; Roels, K.; Ververs, C.; Leemans, B.; Wydooghe, E.; Deforce, D.; Van Soom, A. Proteome of equine oviducal fluid: Effects of ovulation and pregnancy. Reprod. Fertil. Dev. 2016. [CrossRef]

45. Smits, K.; Willems, S.; Van Steendam, K.; Van De Velde, M.; De Lange, V.; Ververs, C.; Roels, K.; Govaere, J.; Van Nieuwerburgh, F.; Peelman, L.; et al. Proteins involved in embryo-maternal interaction around the signalling of maternal recognition of pregnancy in the horse. Sci. Rep. 2018, 8, 5249. [CrossRef]

46. Hebeda, C.B.; Machado, I.D.; Reif-Silva, I.; Moreli, J.B.; Oliani, S.M.; Nadkarni, S.; Perretti, M.; Bevilacqua, E.; Farsky, S.H.P. Endogenous annexin A1 (AnxA1) modulates early-phase gestation and offspring sex-ratio skewing. J. Cell. Physiol. 2018, 233, 6591-6603. [CrossRef]

47. Garrido-Gomez, T.; Dominguez, F.; Quinonero, A.; Estella, C.; Vilella, F.; Pellicer, A.; Simon, C. Annexin A2 is critical for embryo adhesiveness to the human endometrium by RhoA activation through F-actin regulation. FASEB J. 2012, 26, 3715-3727. [CrossRef]

48. Wang, B.; Ye, T.M.; Lee, K.F.; Chiu, P.C.; Pang, R.T.; Ng, E.H.; Yeung, W.S. Annexin A2 acts as an adhesion molecule on the endometrial epithelium during implantation in mice. PLoS ONE 2015, 10, e0139506. [CrossRef]

49. Leffler, H.; Carlsson, S.; Hedlund, M.; Qian, Y.; Poirier, F. Introduction to galectins. Glycoconj. J. 2002, 19, 433-440. [CrossRef]

50. Kim, M.; Kim, S.; Kim, H.; Joo, H.G.; Shin, T. Immunohistochemical localization of galectin-3 in the reproductive organs of the cow. Acta Histochem. 2008, 110, 473-480. [CrossRef]

51. Yang, H.; Lei, C.; Zhang, W. Expression of galectin-3 in mouse endometrium and its effect during embryo implantation. Reprod. Biomed. Online 2012, 24, 116-122. [CrossRef] [PubMed]

52. Holm, P.; Booth, P.J.; Schmidt, M.H.; Greve, T.; Callesen, H. High bovine blastocyst development in a static in vitro production system using SOFaa medium supplemented with sodium citrate and myo-inositol with or without serum-proteins. Theriogenology 1999, 52, 683-700. [CrossRef]

53. Keller, A.; Nesvizhskii, A.I.; Kolker, E.; Aebersold, R. Empirical statistical model to estimate the accuracy of peptide identifications made by MS/MS and database search. Anal. Chem. 2002, 74, 5383-5392. [CrossRef] [PubMed]

54. Nesvizhskii, A.I.; Keller, A.; Kolker, E.; Aebersold, R. A statistical model for identifying proteins by tandem mass spectrometry. Anal. Chem. 2003, 75, 4646-4658. [CrossRef] 